\title{
THE CRYSTAL STRUCTURE OF SYNTHETIC KUTINAITE, $\mathrm{Cu}_{14} \mathrm{Ag}_{6} \mathrm{As}_{7}$
}

\author{
LJILJANA KARANOVIĆCII, DEJAN POLETI ${ }^{\ddagger}$, EMIL MAKOVICKY, \\ TONČI BALIĆ-ŽUNIĆ§ AND MILOTA MAKOVICKY \\ Geological Institute, University of Copenhagen, Øster Voldgade 10, DK-1350 Copenhagen K, Denmark
}

\begin{abstract}
The crystal structure of synthetic kutinaite, $\mathrm{Cu}_{14} \mathrm{Ag}_{6} \mathrm{As}_{7}$, was determined from powder-diffraction data recorded on a Guinier diffractometer and refined by Rietveld method with the program FULLPROF. The final refinement $\left(\Delta / \sigma_{\max }<0.2\right)$ with $31(9$ profile and 23 structural) parameters using 4600 data points and 226 reflections yielded the following agreement indices: $R_{w p}=$ $18.2 \%, R_{p}=13.4 \%, R_{\text {exp }}=14.7 \%, S=1.54, R(B)=1.78 \%$. The cubic structure has $a$ equal to $11.78079(2) \AA$ (standard uncertainties are underestimated by a score-factor of 2.4686) and space group $P m \overline{3} m, Z=4$. Apart from partially ordered Cu vacancies, the arrangement of atoms is very close to that in $F m \overline{3} m$. The $P m \overline{3} m$ structure of kutinaite is a result of the frozen-in partial order of $\mathrm{Cu}$ vacancies which, in a presumed high-temperature $F m \overline{3} m$ structure, should be completely disordered. The atoms $\mathrm{Cu} 2$ and $\mathrm{Cu} 3$ are tetrahedrally coordinated by $\mathrm{As}$, the atoms $\mathrm{Cu} 1$ and $\mathrm{Cu} 4$ (with partial occupancies) have trigonal planar As coordination. Atoms of $\mathrm{Ag}$ form octahedral $\mathrm{Ag}_{6}$ clusters in octahedral cavities of the $\mathrm{Cu}-\mathrm{As}$ framework. On the one hand, the structure of kutinaite contains a multitude of short metal-metal and metal-semimetal contacts, resulting in high coordination-numbers and indicating direct metal-metal interactions. The presence of metal-metal bonding contacts is supported by an electron-density analysis, which gives the following bonding contact limits: $2.70 \AA(\mathrm{Cu}-\mathrm{Cu})$, and $3.05 \AA(\mathrm{Ag}-\mathrm{Cu})$. On the other hand, a network of important $\mathrm{Cu}$-As bonds forms a three-dimensional complex with a nominal net negative charge balanced by nominal positive charges of localized $\mathrm{Ag}_{6}$ complexes. This situation results in two complementary descriptions of the structure of kutinaite: kutinaite as an icosahedral alloy and kutinaite as an arsenide with metal clusters.
\end{abstract}

Keywords: kutinaite, X-ray diffraction, powder method, crystal structure, icosahedral alloy, arsenide, metal clusters.

SOMMAIRE

Nous avons établi la structure cristalline de la kutinaïte synthétique, $\mathrm{Cu}_{14} \mathrm{Ag}_{6} \mathrm{As}_{7}$, à partir de données en diffraction $\mathrm{X}$ obtenues sur poudre, enregistrées avec un diffractomètre Guinier et affinées par la méthode de Rietveld avec le logiciel FULLPROF. L'affinement final $\left(\Delta / \sigma_{\max }<0.2\right)$, avec 31 paramètres ( 9 portant sur le profil et 23 sur la structure), repose sur 4600 données et 226 réflexions, et ont mené aux indices de concordance suivants: $R_{w p}=18.2 \%, R_{p}=13.4 \%, R_{\text {exp }}=14.7 \%, S=1.54, R(B)=$ $1.78 \%$. Le paramètre $a$ de la structure cubique est égal à 11.78079(2) A (l'écart-type est sous-estimé par un facteur de 2.4686); le groupe spatial est $\operatorname{Pm} \overline{3} m, Z=4$. Mis à part les lacunes aux sites du $\mathrm{Cu}$, partiellement ordonnées, l'agencement des atomes se rapproche de celui du groupe spatial $F m \overline{3} m$. La structure $P m \overline{3} m$ de la kutinaïte résulterait de la mise en ordre partielle des lacunes aux sites $\mathrm{Cu}$; dans un précurseur de haute température, dont le groupe spatial est $F m \overline{3} m$, ces lacunes devraient être complètement désordonnées. Les atomes $\mathrm{Cu} 2$ et $\mathrm{Cu} 3$ ont une coordinence tétraédrique, les sites $\mathrm{Cu} 1$ et $\mathrm{Cu} 4$ (partiellement remplis) ont une coordinence trigonale planaire avec les atomes As. Les atomes de Ag forment des agencements octaédriques $\mathrm{Ag}_{6} \mathrm{dans}_{\mathrm{des}}$ cavités octaédriques de la trame $\mathrm{Cu}$-As. D’une part, la structure de la kutinaïte contient une multiplicité de contacts métal-métal et métal-semimétal courts, et donc des coordinences élevées, et une indication d'interactions métal-métal directes. Une analyse de la densité des électrons étaye la présence de ces contacts par liaisons métal-métal, et indique les limites suivantes des contact dans ces liaisons: $2.70 \AA(\mathrm{Cu}-\mathrm{Cu})$, et $3.05 \AA$ ( $\mathrm{Ag}-\mathrm{Cu})$. D'autre part, un réseau de liaisons $\mathrm{Cu}-\mathrm{As}$ importantes définit un complexe tri-dimensionnel ayant une charge négative, neutralisée par les charges positives des complexes localisés $\mathrm{Ag}_{6}$. De cette situation résulte deux descriptions complémentaires de la structure de la kutinaïte. On peut concevoir la kutinaïte comme alliage icosaédrique ou comme un arséniure avec des groupements d'atomes métalliques.

(Traduit par la Rédaction)

Mots-clés: kutinaïte, diffraction X, méthode des poudres, structure cristalline, alliage icosaédrique, arséniure, groupements d'atomes métalliques.

\footnotetext{
Permanent address: Faculty of Mining and Geology, Đušina 7, 11000 Belgrade, Yugoslavia.

Permanent address: Faculty of Technology and Metallurgy, Karnegijeva 4, 11000 Belgrade, Yugoslavia.

E-mail address: tonci@geo.geol.ku.dk
} 


\section{INTRODUCTION}

Kutinaite is the only known copper-silver arsenide. The mineral was first described together with some rare copper arsenides from Černý Důl, Czech Republic by Hak et al. (1970). On the basis of electron-microprobe data, its composition was estimated as $\mathrm{Cu}_{2.07} \mathrm{Ag}_{0.84} \mathrm{As}$, or recalculated to seven As atoms, as $\mathrm{Cu}_{14.49} \mathrm{Ag}_{5.88} \mathrm{As}_{7}$ (Table 1). Kutinaite was also synthesized from premelted charges of this composition at $400^{\circ} \mathrm{C}$. From $\mathrm{X}$ ray powder-diffraction data of both natural and synthetic samples, Hak et al. (1970) determined the unit-cell parameter to be $11.76(1) \AA\left(Z=28, D_{\mathrm{m}}=8.38 \mathrm{~g} \mathrm{~cm}^{-3}\right)$.

The material used in this study was prepared by Makovicky et al. (1979) in the context of the studies in the system $\mathrm{Cu}-\mathrm{Ag}-\mathrm{As}$. Kutinaite was found as a primary phase at $400^{\circ} \mathrm{C}$ and $350^{\circ} \mathrm{C}$. It decomposes incongruently to koutekite $\left(\mathrm{Cu}_{5} \mathrm{As}_{2}\right)$ plus liquid at $478 \pm 2{ }^{\circ} \mathrm{C}$. It was also prepared by Makovicky et al. (1979) from hydrothermal runs above $230 \pm 5^{\circ} \mathrm{C}$, but not below this temperature. It occurs as a metastable reaction-induced rim on $\mathrm{Ag}$ grains at $180^{\circ} \mathrm{C}$ as well, but these rims (and pre-prepared kutinaite) decompose to a mixture containing the low-temperature modification of koutekite as the principal component. It is interesting to note that the composition given by Hak et al. (1970) gave multiphase products, whereas As-enriched compositions yielded nearly pure kutinaite.

The chemical composition of synthesized samples was determined by electron-microprobe analysis. The results of numerous measurements indicate the maximum composition range $\mathrm{Cu}_{14.00-14.56} \mathrm{Ag}_{5.88-6.23} \mathrm{As}_{7}$ (Makovicky et al. 1979). This composition is paralleled by the constancy of the unit-cell parameter, established by a leastsquares method from X-ray powder-diffraction data: $11.782(2) \AA$. This value practically does not differ from the value obtained by Rietveld analysis (Table 1 ).

"Anomalous" kutinaite also was encountered; it exsolved from silver-containing high-temperature " $\beta$ -

TAELE 1. CRYSTAL. DATA FOR KLTTINAITE

\begin{tabular}{|c|c|c|c|c|}
\hline Fartsula & $C_{u_{1}} A_{B_{6}} A_{S_{7}}$ & 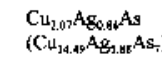 & 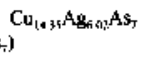 & $\begin{array}{l}\text { "arnornalous" } \\
\mathrm{Cu}_{1}, \mathrm{Ag}_{5,6} \mathrm{As}_{7}\end{array}$ \\
\hline $\begin{array}{l}\text { Formula wejght } \\
\text { Space group } \\
\text { (No.) }\end{array}$ & $\begin{array}{l}2067.62 \\
P m 3 m \\
(221)\end{array}$ & & & \\
\hline$a(A)$ & $11.78079(2)^{\circ}$ & $11.76(1)$ & {$[1.782(2)$} & $\begin{array}{l}11.763(3)= \\
11.753(3)\end{array}$ \\
\hline$f^{2}\left(A^{2}\right)$ & $1635.0254(5)$ & & & \\
\hline$Z$ & 4 & $\begin{array}{l}28 \\
(4)\end{array}$ & 4 & 4 \\
\hline $\begin{array}{l}\text { F(000) } \\
4(\mathrm{~mm})\end{array}$ & $\begin{array}{l}3687.6 \\
42.72]\end{array}$ & & & \\
\hline$D\left(5 \omega^{-9}\right)$ & $D_{\pi}=8.400$ & $D_{\mathrm{m}}=8.39$ & $D_{\mathrm{x}}=8.30$ & \\
\hline Reference & this study & Hak et al. (1970) & Makowichy et & at (1979) \\
\hline
\end{tabular}

- The standard uncertajuties should be multiplied by the cartection factor 2.4686. domeykite" or koutekite on quenching. The most reliable estimate of its composition is $\mathrm{Cu}_{14.7} \mathrm{Ag}_{5.6} \mathrm{As}_{7}$. This copper-rich and silver-poor variety of kutinaite has a unit-cell parameter $a$ of $11.763(3) \AA$; some varieties seem to be still richer in $\mathrm{Cu}$, with $a=11.753(3) \AA$ (Makovicky et al. 1979).

In this paper, we describe the crystal structure of the "normal" synthetic kutinaite. The structure has been solved $a b$ initio by a combination of full-profile fitting of powder-diffraction data and direct methods. It was refined by Rietveld method. In addition, a calculation of the approximate "procrystal" electron density was performed in order to analyze the chemical bonding in the structure.

\section{Experimental Details and Structure Solution}

\section{Sample preparation}

The sample of kutinaite was prepared at $350^{\circ} \mathrm{C}$ by reaction of pure elements in an evacuated silica glass capsule (charge size: $250 \mathrm{mg}$ ). Spectrographically pure copper and silver rods supplied by Johnson Matthey Chemicals (total metallic impurities less than $10 \mathrm{ppm}$ ) were used. Arsenic was obtained from lumps of arsenic (purity 99.9995\%) produced by Fluka.

\section{Electron-microprobe analyses}

The electron-microprobe analyses were performed on the Cameca MS-45 instrument at the Bureau de Recherches Géologiques et Minières (Orléans, France) and the Hitachi XMA-5B instrument at the Geological Institute, University of Copenhagen; synthetic $\mathrm{Cu}_{2.7} \mathrm{As}$ and metals were used as standards (Makovicky et al. 1979). The microprobe-established composition yields the formula $\mathrm{Cu}_{14.35} \mathrm{Ag}_{6.02} \mathrm{As}_{7}$; the pycnometrically determined density is $8.36 \mathrm{~g} \mathrm{~cm}^{-3}$ (Table 1).

\section{$X$-ray powder diffraction}

In order to achieve high resolution, the X-ray powder-diffraction data were collected on a Guinier diffractometer (HUBER, type G600) using $\mathrm{CuK \alpha} \alpha_{1}$ radiation (1.54051 $\AA$ ), an incidence angle of $45^{\circ}$, a $2 \theta$ range of $12-104^{\circ}$, a step width of $0.02^{\circ}$ and a counting time of $8 \mathrm{~s}$. The powdered sample was mounted between two layers of mylar in the specimen holder for transmission geometry. The measured pattern was converted to the Bragg-Brentano geometry by means of a homemade computer program, in order to prepare it for the FULLPROF Rietveld-refinement programs.

\section{Structure solution and refinement}

Only the Bravais lattice (cubic, $P$ ) and the unit-cell parameter of kutinaite (Makovicky et al. 1979; see also JCPDS card 23-0957) were known prior to our investi- 
gation. After an initial full-profile fit with known unitcell parameters, 131 unique structure-factors were extracted using program FULLPROF (Rodríguez-Carvajal 1990, 1998) in a WINPLOTR environment (Roisnel \& Rodríguez-Carvajal 2001). Direct methods were then applied to the extracted dataset with the program SHELXS97 (Sheldrick 1997a). In the first step of the structure solution, the lowest cubic space-group $P 23$ was used. This step yielded positions of five atoms. The positions of the remaining atoms and the correct assignments of atoms were obtained by a combination of the least-squares refinement and difference-Fourier synthesis using program SHELXL97 (Sheldrick 1997b). Already in these steps, it was clear that two copper sites $(\mathrm{Cu} 1$ and $\mathrm{Cu} 4)$ at Wyckoff positions $24 m$ and $8 g$, respectively, are not fully occupied. Therefore, occupancies of these two sites were initially fixed to 0.83 and 0.5 , respectively, according to the formula $\mathrm{Cu}_{14} \mathrm{Ag}_{6} \mathrm{As}_{7}$, which approximates the chemical data.

The atom positions obtained are consistent with the space groups $P m \overline{3}$ and $P m \overline{3} m$. Final refinement was performed in space group $P m \overline{3} m$, since no reasons for lowering the symmetry of the model were noticed, and it yielded slightly better reliability-factors. It is worth emphasizing that the structure can almost equally well be described in space group $F m \overline{3} m$. However, a number of weak but observed reflections, like 210, 211, 300 (221), 321, 410 (322), 330 (411), 421, 332, etc., violate the extinction rules of this space group.

Once the structure model was established, refinement continued by the Rietveld method with the program FULLPROF. Adhering to previously published recommendations (McCusker et al. 1999, Karanović et al. 1999), two of the profile parameters were fixed as $n$ $=9$ (in $n \times \mathrm{FWHM})$ and RLIM $=40^{\circ} 2 \theta$. The profiles were described by the pseudo-Voigt function. The background was modeled using the Fourier filtering method, with window size set to 1000 points.

The powder pattern showed the presence of one broad diffraction peak at about $18^{\circ}$ that was not fitted by the structural model. It corresponds to a prominent maximum due to the mylar. The corresponding region $\left(17.10-18.20^{\circ} 2 \theta\right)$ was excluded from the refinement.

Because of a high correlation between occupancies and displacement factors, the occupations of $\mathrm{Cu} 1$ and $\mathrm{Cu} 4$ sites were refined with the displacement parameters being fixed to the average value of the fully occupied $\mathrm{Cu}$ positions.

The final refinement $\left(\Delta / \sigma_{\max }<0.2\right)$ with 31 (9 profile and 23 structural) parameters using 4600 data points and 226 reflections yielded the following agreement indices: $R_{w p}\left(100\left[\sum w\left(y_{o}-y_{c}\right)^{2} / \Sigma w y_{o}^{2}\right]^{1 / 2}\right)=18.2 \%, R_{p}$ $\left(100 \Sigma\left|y_{o}-y_{c}\right| / \Sigma\left|y_{o}\right|\right)=13.4 \%, R_{\exp }(100[(N-P+$ $\left.\left.C) / \Sigma w y_{0}{ }^{2}\right]-\right)=14.7 \%, S\left(\left[R_{w p} / R_{\text {exp }}\right]^{2}\right)=1.54, R(B)$ $\left(100 \Sigma\left|I_{k}-I_{c k}\right| / \Sigma\left|I_{k}\right|\right)=1.78 \%$, where $y_{o}, y_{c}=$ observed and calculated point-intensities, $w=$ weight, $N$, $P, C=$ number of observations, parameters, and constraints, $I_{k}, I_{c k}=$ "observed" and calculated Bragg-re- flection intensities. The observed and calculated patterns are illustrated in Figure 1, and crystal data are given in Table 1. It is obvious that a well-known problem of underestimated standard uncertainties in the Rietveld analysis exists (Bérar \& Lelann 1991). Even after a correction by a program-proposed score-factor of 2.4686 , standard uncertainties for kutinaite are still considered underestimated. The largest peak in a final difference Fourier map was $0.54 e \AA^{-3}, 0.33 \AA$ from $\mathrm{Ag} 3$, and the largest hole was $-0.59 e \AA^{-3}, 1.06 \AA$ from $\mathrm{Cu} 3$. The refined structural parameters are listed in Table 2. Figure 2 shows a stereoplot of the structure.

\section{DESCRIPTION OF THE StruCtURE}

\section{General and space-group considerations}

The unit-cell parameter of kutinaite obtained in the present study (Table 1) is practically the same as the value given by Makovicky et al. (1979), and about 0.02 $\AA$ A higher than the value of Hak et al. (1970). The calculated density is also close to the earlier published values. The structure determination results in a chemical formula (Table 1) that is in a very good accordance with the electron-microprobe results of Makovicky et al. (1979).

As already noticed in the experimental section, the structure of kutinaite is very close to an $F m \overline{3} m$ arrangement. In the $F$-lattice description, the kutinaite structure contains one silver site [Ag1,Ag2,Ag3], two copper sites $[\mathrm{Cu} 1, \mathrm{Cu} 4]$ and $[\mathrm{Cu} 2, \mathrm{Cu} 3]$, and two arsenic sites [As1,As2] and [As3,As4]. It can be seen from coordination characteristics (Table 3) that the differences amount to small distortions of polyhedra, with a split of $F m \overline{3} m$ sites into 2 (or 3 ) configurationally similar but crystallographically distinct sites. This fact is further supported by geometrical parameters of the polyhedra (Balić-Žunić \& Makovicky 1996, Makovicky \& BalićŽunić 1998), also listed in Table 3. Therefore, in the description below, the split sites will be grouped according to their "parent" $F m \overline{3} m$ site.

TABLE 2. KUTINAITE: ATOMIC COORDINATES, ISOTROPIC DISPLACEMENT PARAMETERS AND OCCUPANCIES

\begin{tabular}{llllll}
\hline & \multicolumn{1}{c}{$y$} & \multicolumn{1}{c}{$z$} & $B_{\text {iso }}\left(\AA^{2}\right)$ & Occupancy \\
Atom ${ }^{\dagger}$ & \multicolumn{1}{c}{$x$} & & & & \\
\hline & & & & & \\
Ag1 $(12 h)$ & $0.323(1)$ & 0.5000 & 0.0000 & $2.5(4)$ & 1 \\
Ag2 (6e) & $0.178(2)$ & 0.0000 & 0.0000 & $1.8(9)$ & 1 \\
Ag3 (6f) & $0.187(2)$ & 0.5000 & 0.5000 & $2.6(7)$ & 1 \\
As1 (12f) & 0.5000 & $0.250(2)$ & $0.250(2)$ & $1.9(7)$ & 1 \\
As2 (12i) & 0.0000 & $0.248(2)$ & $0.248(2)$ & $2.0(7)$ & 1 \\
As3 (3d) & 0.5000 & 0.0000 & 0.0000 & $1.0(9)$ & 1 \\
As4 (1b) & 0.5000 & 0.5000 & 0.5000 & $3 .(1)$ & 1 \\
Cu1 $(24 m)$ & $0.331(2)$ & $0.331(2)$ & $0.165(3)$ & $2.3^{*}$ & $0.84(1)$ \\
Cu2 (24m) & $0.123(1)$ & $0.123(1)$ & $0.383(2)$ & $1.9(5)$ & 1 \\
Cu3 (8g) & $0.382(2)$ & $0.382(2)$ & $0.382(2)$ & $3.0(1.0)$ & 1 \\
Cu4 (8g) & $0.167(5)$ & $0.167(5)$ & $0.167(5)$ & $2.3^{*}$ & $0.52(3)$ \\
& & & & &
\end{tabular}

'Wyckoff positions are given in parentheses. * Fixed values. 
The spatial distribution of As can be approximated as a lattice complex $8 F(a / 2)-F(a)$, i.e., the Wyckoff site $(0,0,0)$ of eight $F$-centered subcells minus the Wyckoff site $(0,0,0)$ of the full cell. The latter site is occupied by an octahedral group, $\mathrm{Ag}_{6}$.

On the one hand, the structure of kutinaite contains a multitude of short metal-metal and metal-semimetal contacts, resulting in high coordination-numbers $(\mathrm{CN})$ and indicating direct metal-metal interactions. On the other, a network of important $\mathrm{Cu}-\mathrm{As}$ bonds forms a three-dimensional complex with a nominal net negative charge balanced by nominal positive charges of localized $\mathrm{Ag}_{6}$ complexes. This situation results in two complementary descriptions of the structure, given in the following text.

\section{Kutinaite as an icosahedral alloy}

Based on the first of the two concepts used to describe the structure, a sizable portion of the kutinaite structure can be described as a boxwork of interpenetrating and variously distorted icosahedra. [As1,As2] are in flattened icosahedra elongate parallel to $\langle 110\rangle$, in a plane of four $\mathrm{Ag}$ atoms that form a rectangle with [As1,As2] in the center (Fig. 3a). The Ag-As distances are of the order $3.03-3.10 \AA$, whereas the $\mathrm{Cu}$-As distances, to the remaining vertices of the icosahedron, are
2.38-2.61 A (Table 3). If only the distances below 3.0 $\AA$ are considered, [As1,As2] have 8-fold coordination with copper. Each arsenic icosahedron interpenetrates four [Cu1, Cu4] icosahedra and four [Cu2, Cu3] polyhedra, as well as four Ag-based polyhedra. The ellipsoidally elongate As-"icosahedra" form the edges of large tetrahedra that have $\mathrm{Ag}_{3}$ groups as their corners, and occupy every subcell. This makes six halves of As-based "icosahedra" per subcell.

The [As3,As4] site at $(0,0,1 / 2)$ is surrounded by eight $\mathrm{Cu} 2$ or $\mathrm{Cu} 3$ atoms at the vertices of a regular cube (Fig. 3b, Table 3). An additional six Ag atoms (at $3.80 \AA$ for As3 and $3.68 \AA$ for As4) make $\mathrm{AgCu}_{4}$ pyramids on the surface of the cube, forming together a "stella sexangula" cluster of metal atoms. [As1,As2] icosahedra share edges only with the [As3,As4] cubes.

Each $\mathrm{Ag}$ is a part of an octahedral $\mathrm{Ag}_{6}$ cluster; the $\mathrm{Ag}-\mathrm{Ag}$ distances vary little (2.95-3.04 $\AA$ ), and only slightly exceed those in pure $\mathrm{Ag}(2.89 \AA)$. Each octahedron face is capped by an $\mathrm{Ag}_{3} \mathrm{Cu}$ tetrahedron not belonging to the As-based icosahedral volumes and containing the $\mathrm{Cu} 1$ or $\mathrm{Cu} 4$ atom (Fig. 3c); in this way, a "stella octangula" (O'Keeffe \& Hyde 1996) occurs enclosed by the surrounding icosahedra. The coordination polyhedron of $\mathrm{Ag}$ is a square antiprism with opposite bases respectively formed by four $\mathrm{Ag}$ and four $\mathrm{Cu} 2$ (or $\mathrm{Cu} 3$ ) atoms and all triangular faces capped, the latter

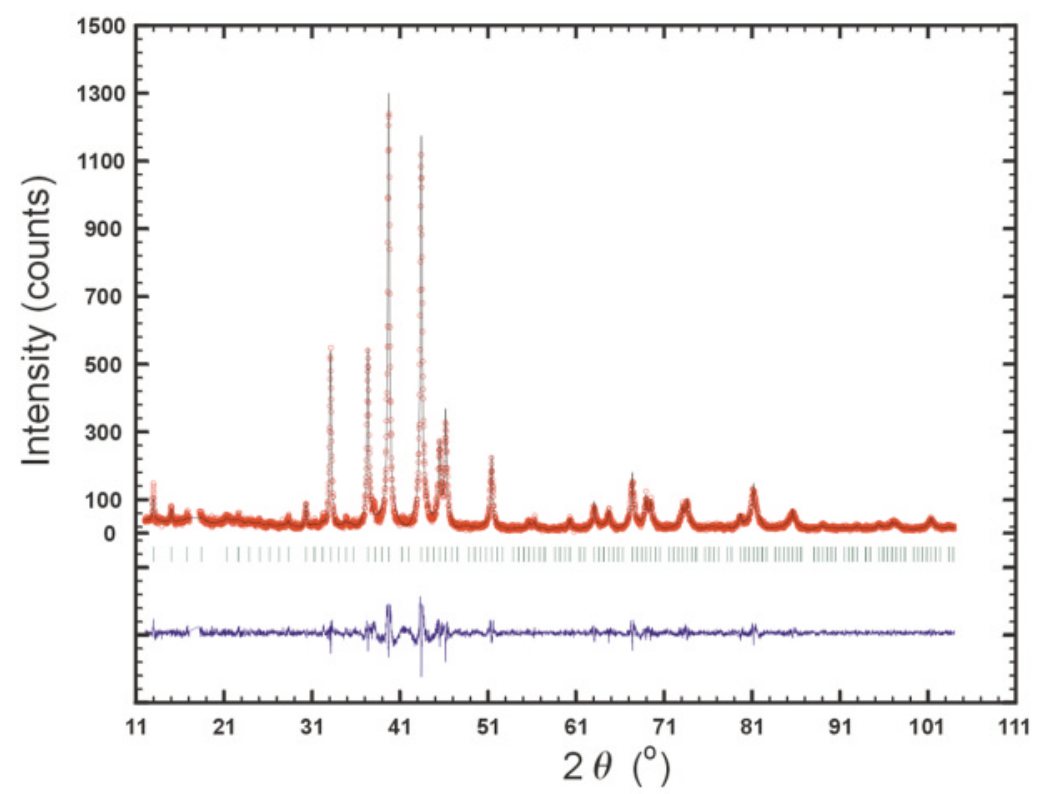

FIG. 1. Observed, calculated and difference X-ray powder patterns of kutinaite. The small circles represent the observed data-points, and the solid black line, the calculated pattern; the difference curve is plotted below. The row of tick marks indicates the positions of the peaks. 
giving a series of eight overlapping, low pentagonal pyramids having As or [ $\mathrm{Cu} 1, \mathrm{Cu} 4]$ as apices. The resulting $\mathrm{Ag}$ polyhedron has a $\mathrm{CN}$ equal to 16 , and atoms of one kind arranged in levels perpendicular to the approximate $\overline{8}$ fold-axis. The Ag3 polyhedron is the least distorted of the three Ag coordination polyhedra (Table 3 ).

The $[\mathrm{Cu} 1, \mathrm{Cu} 4]$ sites are surrounded by a complete icosahedron (Fig. 3d), constituted by six $\mathrm{Cu}$, three As and three Ag vertices. Arsenic atoms form a coordination triangle about the central $\mathrm{Cu}$ atom (Table 3); the part of an icosahedron that opposes Ag consists entirely of $\mathrm{Cu}$ with significantly short $\mathrm{Cu}-\mathrm{Cu}$ distances (Table 3). The $\mathrm{Cu} 4$ icosahedron lies on a threefold rotoinversion axis, and $\mathrm{Cu} 1$ has only approximately threefold symmetry; in particular, the distances to "equatorial" Cu vary significantly (Table 3). These icosahedra are slightly elongate along the exact or the approximate $\overline{3}$ axis.

Each subcell contains four copper icosahedra of this type (3 $\mathrm{Cu} 1$ and $1 \mathrm{Cu} 4$ icosahedron) arranged in a tetrahedral group and interpenetrating each other by means of common pentagonal-bipyramidal volumes. Each of them shares three $\mathrm{Ag}_{2} \mathrm{As}$ faces with $\mathrm{Cu}$ icosahedra from the adjacent subcells.

The $[\mathrm{Cu} 2, \mathrm{Cu} 3]$ polyhedra (coordination number 13 ) can be described (Fig. 3e) as (1) a trigonal antiprism of $\mathrm{Cu}$ atoms with all side faces capped by $\mathrm{Ag}$ and $\mathrm{As}$ in alternation, and with one base capped by a "pressed-in" [As3,As4] atom on a three-fold axis or, alternatively, as (2) an approximate hexatetrahedron of $\mathrm{Cu}, \mathrm{Ag}$ and $\mathrm{As}$ around the central $\mathrm{Cu}$ atom, with the fourth $\mathrm{Ag}$ corner (on the imaginary $\overline{4}$ axis) missing. Ag is in triangular coordination around $[\mathrm{Cu} 2, \mathrm{Cu} 3]$; the $\mathrm{Ag}-[\mathrm{Cu} 2, \mathrm{Cu} 3]$ distances are significantly larger than the $\mathrm{Ag}-[\mathrm{Cu} 1, \mathrm{Cu} 4]$ distances (Table 3). When comparing $\mathrm{Cu} 2$ with $\mathrm{Cu} 3$, the lower asymmetry in the $\mathrm{Cu}$ and $\mathrm{Ag}$ ligands of $\mathrm{Cu} 3$ is compensated by higher asymmetry in the $\mathrm{As}-\mathrm{Cu}$ distances (Table 3). At least one $\mathrm{Cu} 2-\mathrm{Ag} 2$ and two $\mathrm{Cu} 2-$ $\mathrm{Cu} 2$ contacts can be classified as non-bonding because of longer interatomic distances (Table 3).

Each $[\mathrm{Cu} 2, \mathrm{Cu} 3]$ polyhedron is penetrated by three polyhedra of the same kind. Furthermore, it shares pentagonal bipyramidal volumes with three $[\mathrm{Cu} 1, \mathrm{Cu} 4]$ icosahedra. In fact, the $[\mathrm{Cu} 2, \mathrm{Cu} 3]$ polyhedron can be also described as an icosahedron with one triangular face (3Cu2 or $3 \mathrm{Cu} 3$, respectively) extended by a downpressed, capping As atom (As3 or As4, respectively); this increase in $\mathrm{CN}$ from 12 to 13 is aided by concentrating the three $\mathrm{Ag}$ atoms into a ring that is adjacent to the extended face.

We can consider the icosahedral interpretation of the kutinaite structure as a result of icosahedral accretion, i.e., with the accretion of interpenetrating icosahedra starting from a selected origin. In this process, the nearest, mutually overlapping icosahedra (in the first shell) are in principle centered on every vertex of the initial icosahedron and share with it a pentagonal-bipyramidal volume; one vertex of the accreted icosahedron is always the central atom of the initial icosahedron (Fig. 4). The next shell of icosahedra accretes in an analogous way upon the icosahedra of the first shell. Their centers and the initial centering atom at the origin are
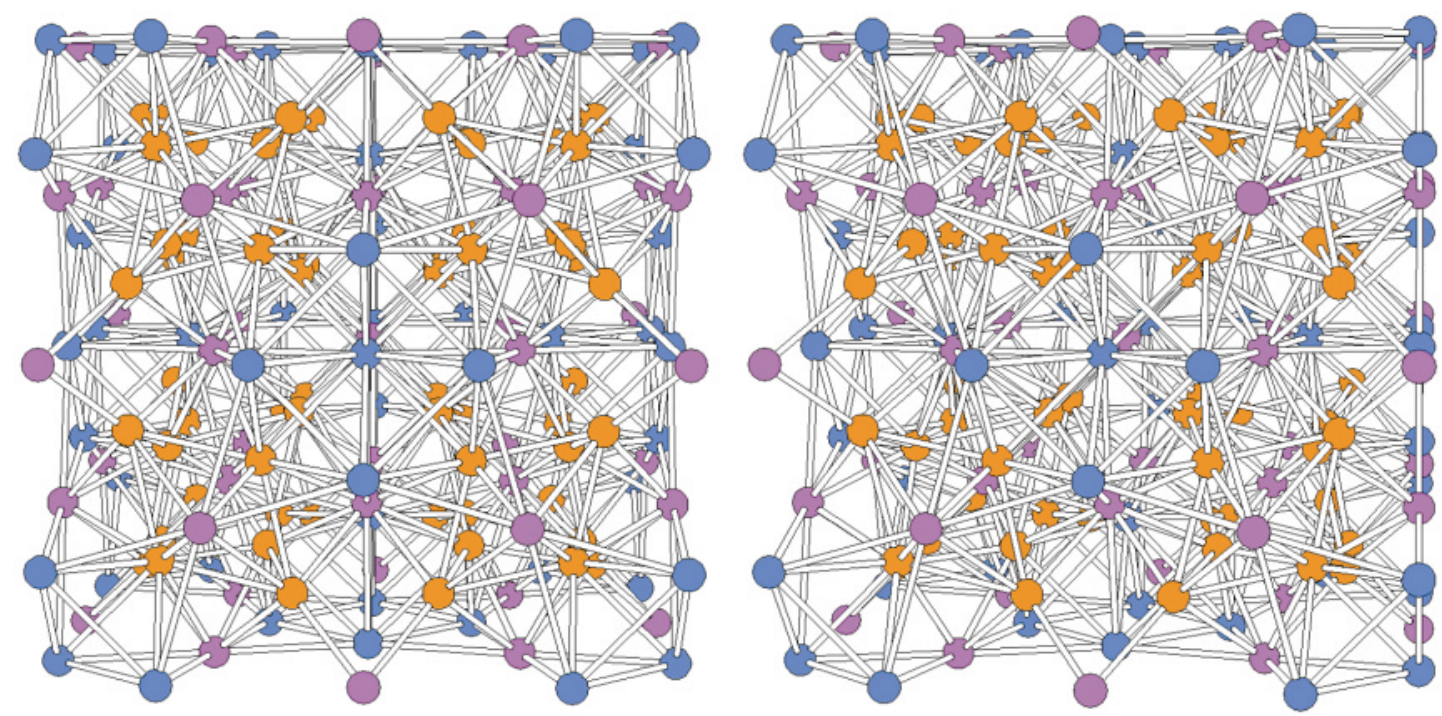

FIG. 2. Stereoview of the structure of kutinaite. Legend: Ag: blue, As: purple, Cu: orange. 


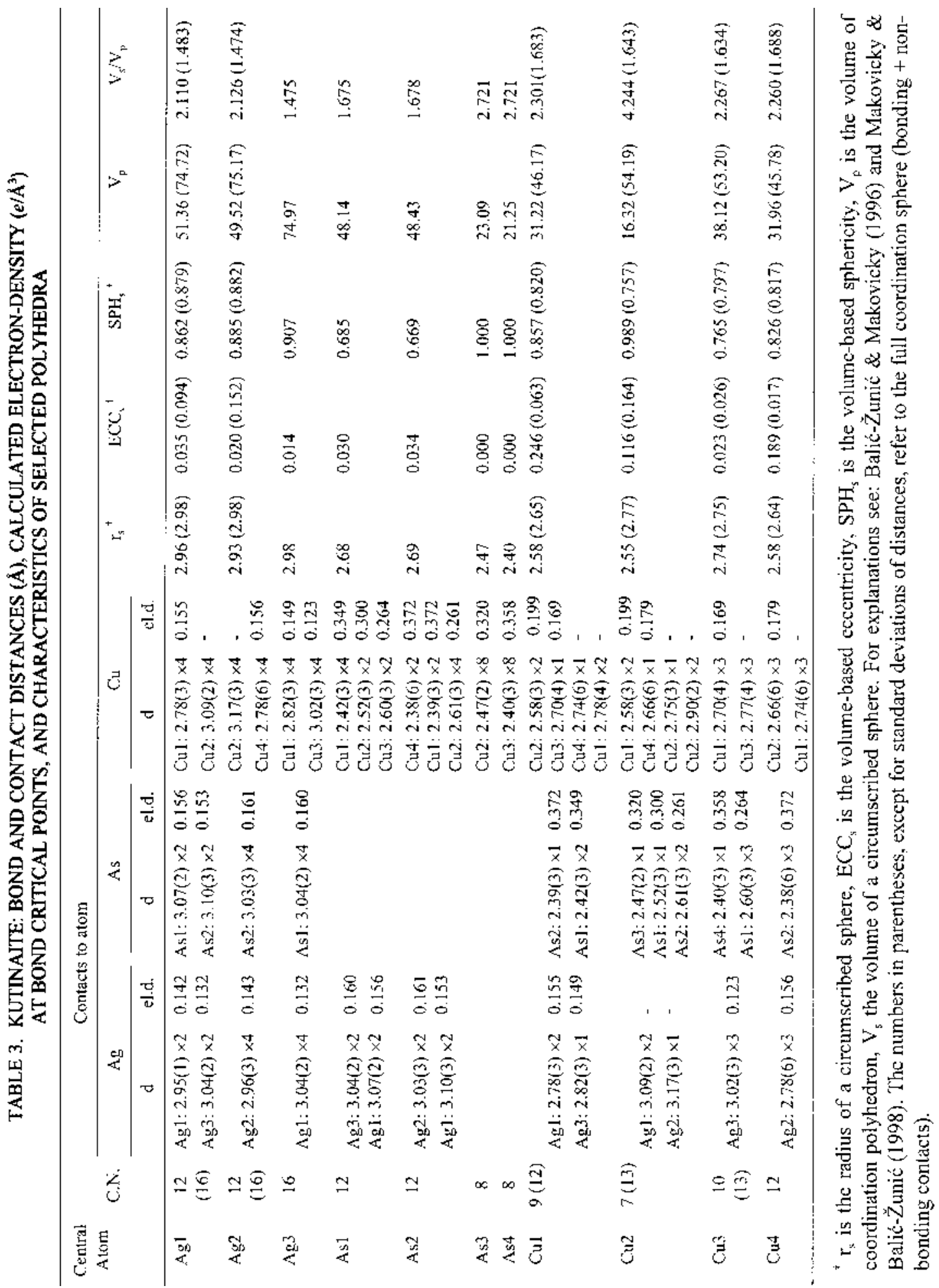


then the opposing vertices of a pair of tetrahedra that share a triangular face. This face is the contact face of the initial and second-shell icosahedron.

Selecting a $[\mathrm{Cu} 1, \mathrm{Cu} 4]$ icosahedron as the starting body, all polyhedra at its vertices start their accretion as icosahedra of the first shell; their shape (Fig. 4) may eventually be altered when they grow beyond the confines of the initial icosahedron. In the cubic subcell defined above, in which this [ $\mathrm{Cu} 1, \mathrm{Cu} 4]$ polyhedron is placed, the first shell consist of three [Cu1, Cu4]-icosahedra, three icosahedra of $[\mathrm{Cu} 2, \mathrm{Cu} 3]$, these being grossly distorted at one end, and three elongate icosahedra of [As1,As2] (Fig. 4). Finally, three first-shell Ag polyhedra take part in this cluster; they develop into the above-mentioned $\overline{8} 2 \mathrm{~m}$ polyhedra, departing most from the icosahedral motif. Each of them has to satisfy simultaneously configurational requirements of four "starting" [Cu1, Cu4] icosahedra, arranged around a four-fold axis.

Second-shell polyhedra around the initial [Cu1, $\mathrm{Cu} 4]$ icosahedron, obtained by continuing the icosahedral accretion, are three times two Ag polyhedra, three As icosahedra opposite those developed directly on the vertices of the initial icosahedron, only one $[\mathrm{Cu} 2, \mathrm{Cu} 3]$ "quasi-icosahedron", and three [Cu1,Cu4] icosahedra straddling the subcell boundaries but still derived by the process of icosahedral accretion. Three more [Cu2,Cu3] second-shell contacts materialize across subcell boundaries by a non-icosahedral accretion. With the exception of the above-mentioned $\mathrm{Cu} 1$ and As icosahedra, the icosahedral accretion process is interrupted on subcell boundaries, especially by the presence of the Ag polyhedra with configurations altered on four-fold axes and, in an analogous way, by the need to accommodate a $[\mathrm{Cu} 2, \mathrm{Cu} 3]_{8}$ As hexahedron.

Distortion of coordination polyhedra with coordination numbers 12, 13 and 16 from ideal "spherical" shapes can be seen in Table 3 , together with the eccentricity of central atoms in them. In spite of the structure distortion from $F m \overline{3} m$ to $P m \overline{3} m$, analogous polyhedra exhibit similar departures from sphericity; they may differ substantially, however, in the eccentricity of the central atom. The reader should bear in mind, however, the potentially limited accuracy of the structure analysis using powder-diffraction data instead of single-crystal data.

What is the influence of partly occupied positions on $\mathrm{Cu}$ coordination polyhedra? In comparison with the fully occupied copper sites, there is a marked decrease in the $\mathrm{Cu}-\mathrm{Ag}$ and $\mathrm{Cu}-\mathrm{As}$ distances for the $\mathrm{Cu} 1$ position, matched only partially by a decrease in $\mathrm{Cu}-\mathrm{Cu}$ distances. A general decrease of distances is observed for the $\mathrm{Cu} 4$ site (Table 3). Of course, the decrease in the $\mathrm{Cu}-\mathrm{As}$ distances can also be ascribed to coordination number 3 in the case of $[\mathrm{Cu} 1, \mathrm{Cu} 4]$ instead of coordination number 4 at the $[\mathrm{Cu} 2, \mathrm{Cu} 3]$ site.

Owing to the partial occupancy of the ligand at $\mathrm{Cu} 1$ and $\mathrm{Cu} 4$ sites, the effective coordination of the $[\mathrm{Cu} 1, \mathrm{Cu} 4]$ site will be $10.6-10.9$, that of $[\mathrm{Cu} 2, \mathrm{Cu} 3]$ site
12.2-12.5, and that of an Ag site, 14.1-15.4. The [As1,As2] icosahedron will be reduced to $10.7<\mathrm{CN}<$ 11.4 as well.

\section{Kutinaite as an arsenide with metal clusters}

If the network of As- $\mathrm{Cu}$ bonds is examined, the crystal structure of kutinaite can be described as composed of two distinct cuboctahedral configurations. [Cu2, Cu3] forms cube-like clusters of eight fully occupied positions; in turn, each copper atom has four tetrahedrally arranged As ligands. The $\mathrm{CuAs}_{4}$ tetrahedra share three edges with adjacent such tetrahedra. Groups of eight tetrahedra form cuboctahedral clusters centered on As3 or As 4 atoms and situated at $1 / 2,0,0$, etc., with the square faces of cuboctahedron unoccupied (Fig. 5a).

The alternative cuboctahedra, at $0,0,0$, etc., are of the same size, with triangular faces occupied by $[\mathrm{Cu} 1, \mathrm{Cu} 4]$. They are filled by the $\mathrm{Ag}_{6}$ octahedra in such a way that each Ag atom lies under the center of a square face (Fig. 5b).

These two types of cuboctahedra alternate in a cubic three-dimensional array, sharing the square faces with the opposite kind. They leave unfilled octahedral spaces $\mathrm{As}_{6}$ formed by [As1,As2] atoms at $1 / 4,1 / 4,1 / 4$, etc. Four alternative faces of these $\mathrm{As}_{6}$ octahedra are occupied by three-coordinated $[\mathrm{Cu} 1, \mathrm{Cu} 4]$, whereas the remaining four faces face the tetrahedrally coordinated $[\mathrm{Cu} 2, \mathrm{Cu} 3]$ (Fig. 6).

The $[\mathrm{Cu} 1, \mathrm{Cu} 4]-[\mathrm{Cu} 1, \mathrm{Cu} 4]$ distances across the octahedral $\mathrm{As}_{6}$ volume (i.e., within a tetrahedron of four $[\mathrm{Cu} 1, \mathrm{Cu} 4]$ atoms) are of the order of 2.74-2.78 $\AA$. It is the $[\mathrm{Cu} 2, \mathrm{Cu} 3]-[\mathrm{Cu} 1, \mathrm{Cu} 4]$ distances, from just outside of $\mathrm{As}_{6}$ octahedron, and across its body, that are the locus of shortest $\mathrm{Cu}-\mathrm{Cu}$ contacts $(2.58-2.70 \AA$, always from one $[\mathrm{Cu} 2, \mathrm{Cu} 3]$ to three $[\mathrm{Cu} 1, \mathrm{Cu} 4]$ and vice versa).

Thus, the distribution of $\mathrm{Cu}-\mathrm{Cu}$ interactions suggests an alternative way of cluster description: a grouping of four $[\mathrm{Cu} 2, \mathrm{Cu} 3] \mathrm{As}_{4}$ tetrahedra into a supertetrahedron (O’Keeffe \& Hyde 1996) which, in addition, has its tetrahedron faces centered by $[\mathrm{Cu} 1, \mathrm{Cu} 4]$ in triangular coordination (Fig. 6). Each supertetrahedron spans 1/8 of the unit cell (one "F-subcell"); it incorporates the abovementioned $\mathrm{As}_{6}$ octahedron. Supertetrahedra share all edges with adjacent supertetrahedra. Across these edges, the only other short $\mathrm{Cu}-\mathrm{Cu}$ interactions occur (Fig. 7).

Supertetrahedra delineate large octahedral volumes at $0,0,0$, etc., in which the octahedral $\mathrm{Ag}_{6}$ clusters reside (Fig. 7). Each silver atom is bound to four arsenic atoms, and every group of three silver atoms interacts with a $[\mathrm{Cu} 1, \mathrm{Cu} 4]$ atom in the wall of the octahedral cavity.

Synthesis experiments show that kutinaite is metastable at ambient temperature. We tentatively propose that both the unequal occupancy of $\mathrm{Cu} 1$ and $\mathrm{Cu} 4$ sites and the structure collapse from $F m \overline{3} m$ to $P m \overline{3} m$ represent two mutually connected phenomena resulting from 
a
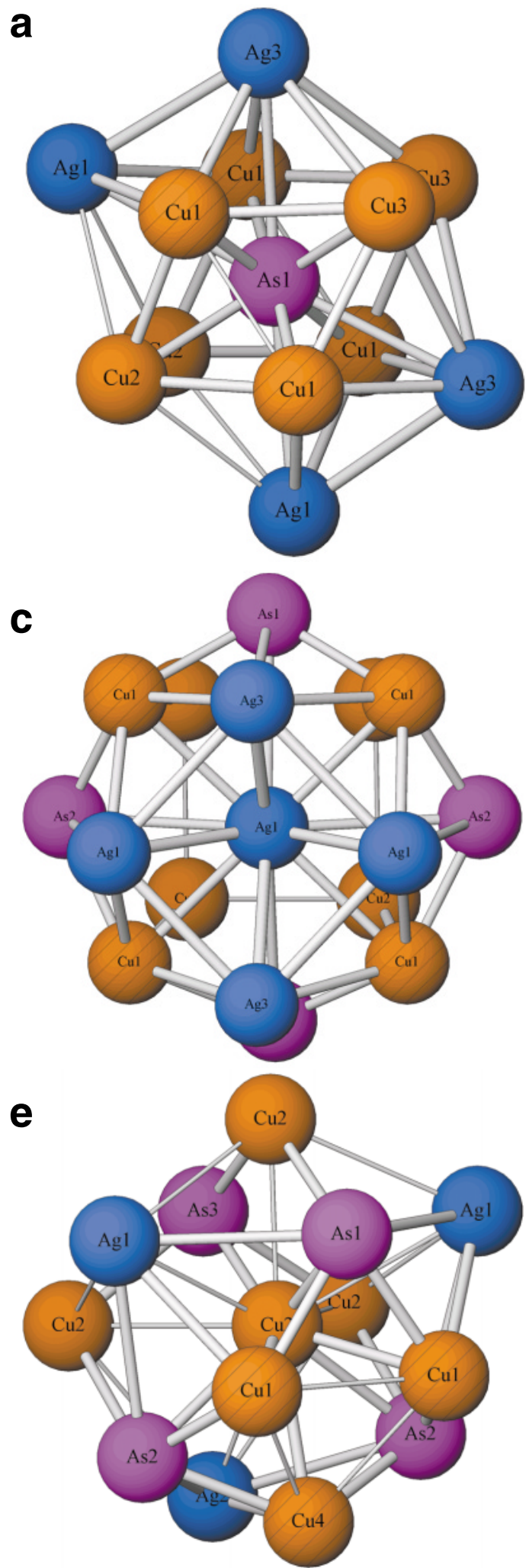
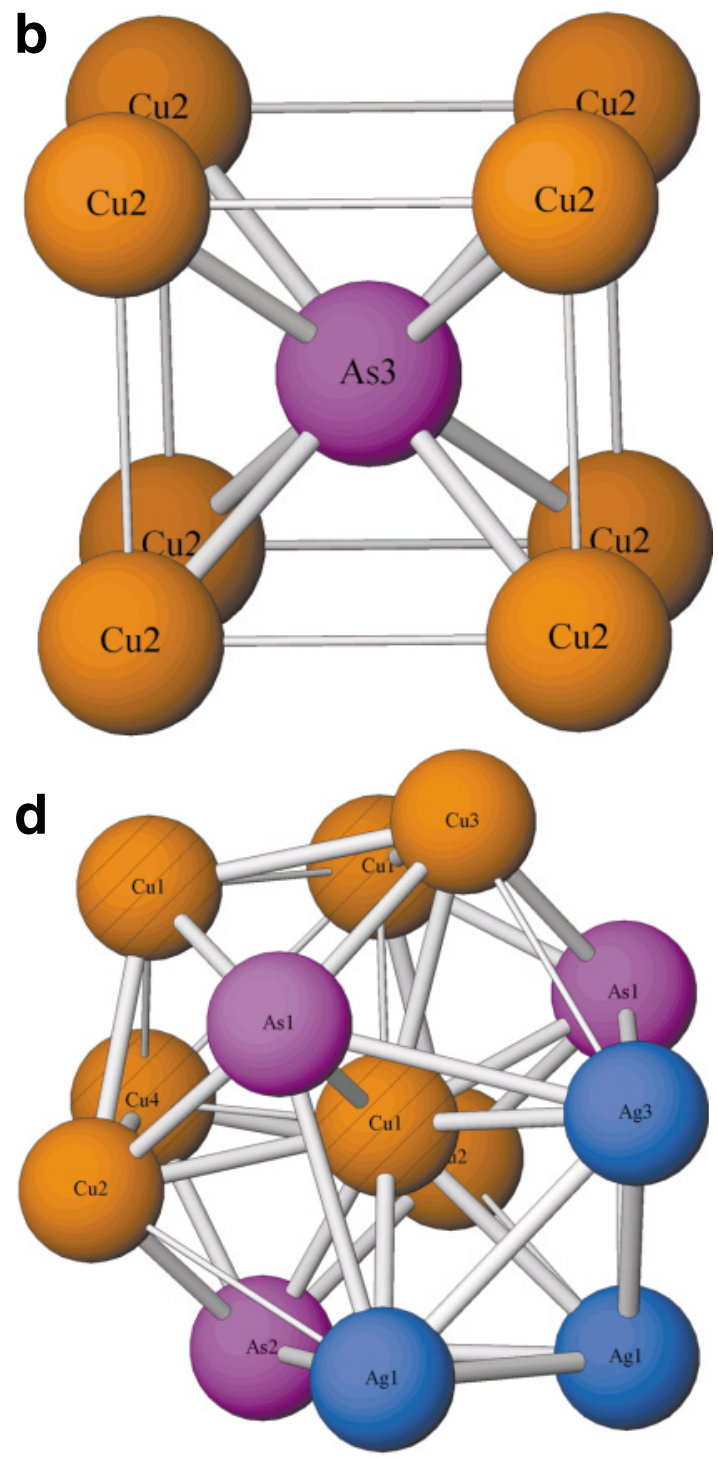

FIG. 3. Coordination polyhedra of (a) As1, (b) As3, (c) Ag1, (d) $\mathrm{Cu} 1$ and (e) $\mathrm{Cu} 2$ atoms. Thick and thin lines indicated are bonding and non-bonding contacts, respectively. Partially occupied positions are ruled. 


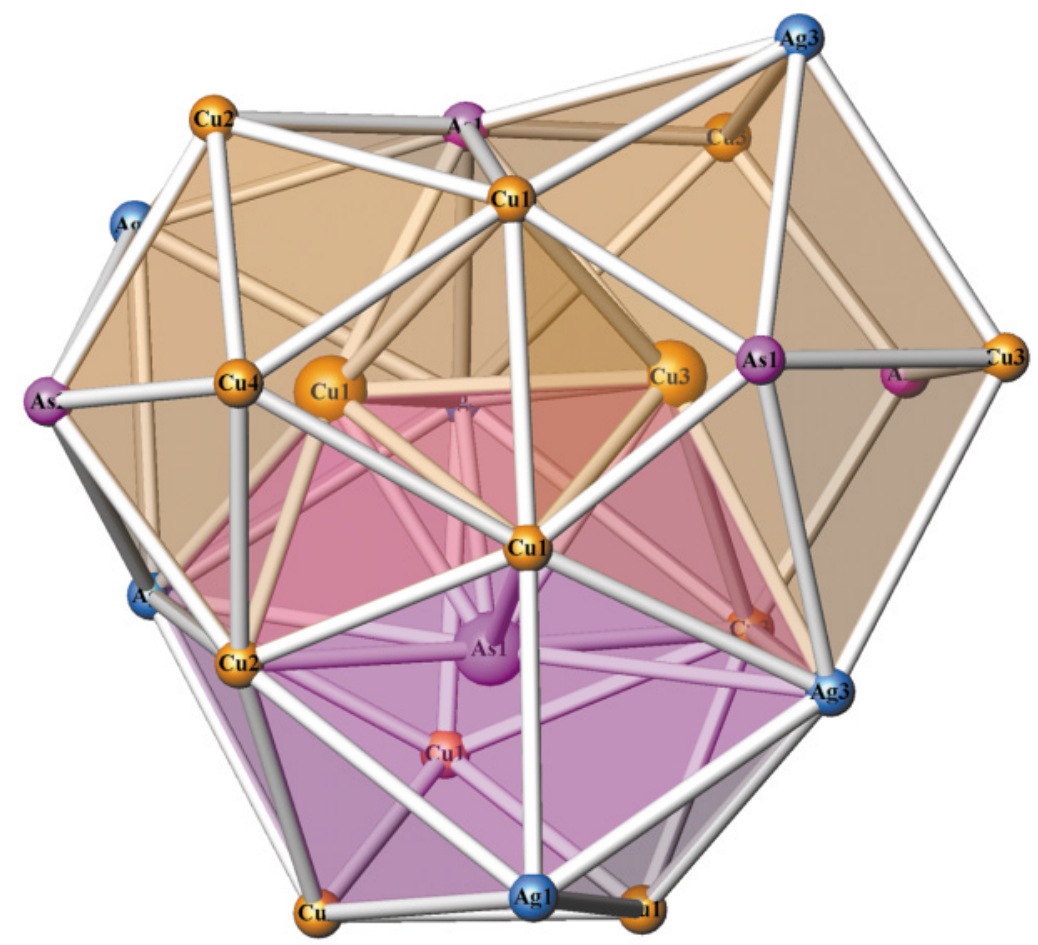

FIG. 4. Accretion of a $\mathrm{Cu} 1$ icosahedron and a $\mathrm{Cu} 3$ polyhedron (coordination number 13) on the As1 icosahedron. Cu coordination polyhedra are indicated by orange shading, and the As icosahedron is pink.

a

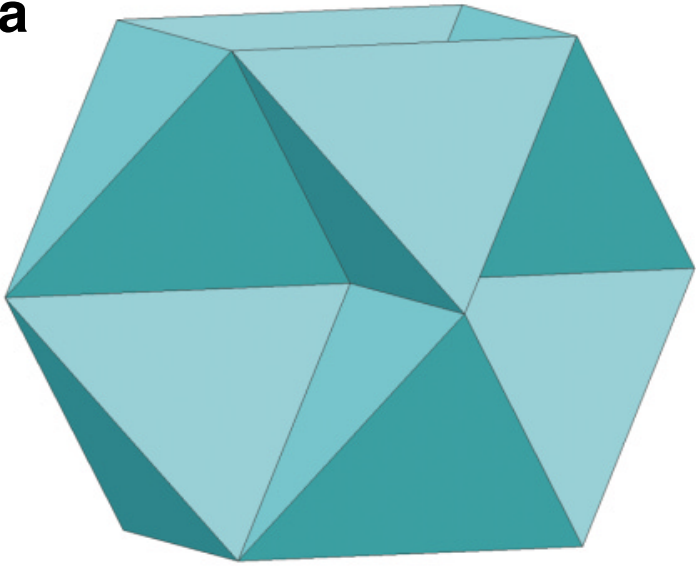

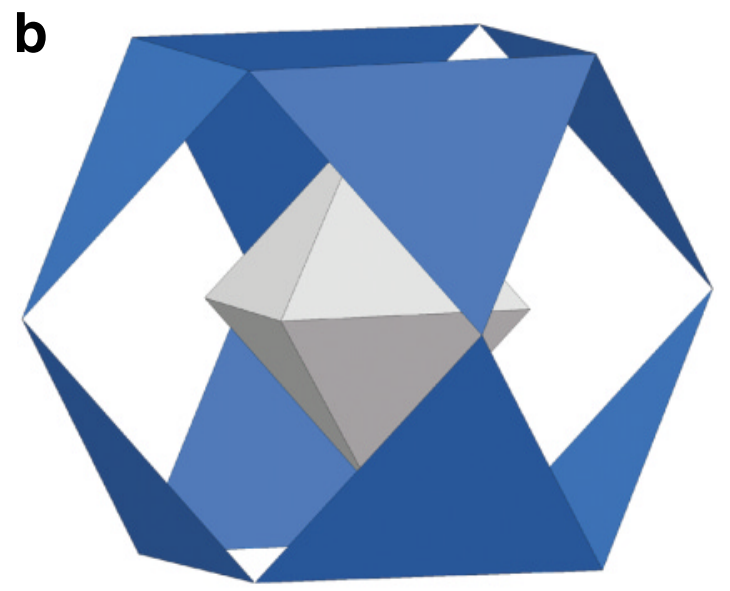

FIG. 5. Clusters of $\mathrm{Cu}-\mathrm{As}$ coordination polyhedra in kutinaite. (a) Cuboctahedron of edge-sharing [Cu2,Cu3]As 4 tetrahedra, (b) cuboctahedron of $[\mathrm{Cu} 1, \mathrm{Cu} 4] \mathrm{As}_{3}$ coordination triangles enclosing an $\mathrm{Ag}_{6}$ cluster. 
quenching to, and a prolonged stay at, the metastable state.

\section{ReLATED Compounds}

Kutinaite is the only known copper-silver arsenide. No silver arsenide has been structurally characterized so far, but structures of five copper arsenides are described in literature. They are: $\alpha$-domeykite, $\mathrm{Cu}_{3} \mathrm{As}$ (Iglesias \& Nowacki 1977), high-temperature domeykite, or "metadomeykite" (Mansmann 1965), koutekite, $\mathrm{Cu}_{5} \mathrm{As}_{2}$ (Liebisch \& Schubert 1971), $\mathrm{Cu}_{2} \mathrm{As}$ (Naud \& Priest 1972) and $\mathrm{Cu}_{3} \mathrm{As}_{4}$ (Blendl \& Range 1982).

More or less distorted polyhedra with coordination numbers from 9 to 15 are found in all lower arsenides of copper. A highly deformed icosahedron exists only around one of the three copper sites in "metadomeykite" (Mansmann 1965). The presence of very distorted $\mathrm{CuAs}_{4}$ tetrahedra is a general characteristic of the copper arsenides, and this is their main point of similarity to the kutinaite structure. Only in the case of "metadomeykite" was the existence of $\mathrm{CuAs}_{3}$ triangles documented as well. $\mathrm{CuAs}_{4}$ tetrahedra in the copper arsenides share their corners, edges or faces, forming layers of tetrahedra in $\mathrm{Cu}_{2} \mathrm{As}$ (Naud \& Priest 1972) or extended three-dimensional networks in the other arsenides. The formation of supertetrahedra is not observed.

The structure of $\mathrm{Cu}_{3} \mathrm{As}_{4}$ (Blendl \& Range 1982) consists of $\mathrm{Cu}_{6}$ hexagons arranged in columns and interconnected by $\mathrm{As}_{3}-\mathrm{As}_{3}$ units. In that structure, $\mathrm{Cu}$ coordinations are represented by $\left[\mathrm{CuCu}_{2} \mathrm{As}_{2}\right]$ tetrahedra (each $\mathrm{Cu}$ is bonded to $2 \mathrm{Cu}$ and $2 \mathrm{As}$ ), whereas $\mathrm{As}$ appears in three different types of coordinations [AsCu $\left.{ }_{2}\right],\left[\mathrm{AsAsCu}_{2}\right]$, and [AsAs 3 ], respectively, which makes this copper arsenide not directly comparable to kutinaite.

\section{Bonding and Valence Calculations}

As is evident from the previous description, the structure contains numerous interatomic contacts with a large, rather continuous range of distances. These contacts include both metal-semimetal and metal-metal ones. It is difficult from distances alone to judge upon the bonding or non-bonding nature of these, and therefore a bonding analysis based upon the topological characteristics of electron density was undertaken using the concept of Bader (1990). A structural bonding contact is characterized by the presence of a bond critical point. Such a point is a minimum electron-density point in an electron-density concentration (a bond path) connecting the nuclei of two bonded atoms. Alternatively, a bond critical point can be described as a maximum of electron density on a surface of zero-flux in an electrondensity gradient separating domains of two bonded atoms. This second characteristic is used for a search of bond critical points, performed by our own program for determination of atomic domains based on a topology of electron density.

The electron-density model used is that of a procrystal, where the electron density of a crystal is calculated as a sum of individual "free-atom" electron densities centered on the positions of atoms in a crystal structure (Spackman \& Maslen 1986). Although inevitably an approximation (especially in the treatment of valence electrons), this model has yielded satisfactory results for many crystal-chemical properties, see, e.g., Spackman \& Maslen (1986) and Gibbs et al. (1992). It can be expected to reveal relatively accurately at least the positions of the most important bond critical points in a structure.

For calculation of electron densities associated with individual atoms, the coefficients of atomic functions were used as given by Clementi \& Roetti (1974). The calculation procedure corresponds to that described in Gibbs et al. (1992). Electron densities and their gradients were obtained as a sum over all atoms inside an effective distance. The latter distance for an atomic species is determined as the one at which its electron density falls below $0.0001 \mathrm{e} / \AA^{3}$. Zero-flux electron-density surfaces of an atomic domain are then determined by searching in random directions away from the nucleus and finding the points that limit the region in which the electron-density gradient converges upon the atom investigated. Subsequently, a search for a point with maximum electron-density is performed on each atom-atom (domain-domain) contact surface. If such a point exists on a surface, and gradients on both sides lead to the atoms of the pair considered, it is recorded as a bond critical point. In a case where the gradient leads along the investigated surface to the contact surface of another atom-atom pair, the investigated surface is considered only a contact, but not a bonding surface.

The calculations confirmed all atomic contacts previously described (Table 3), except for $\mathrm{Cu} 2-\mathrm{Cu} 2$ and $\mathrm{Cu} 3-\mathrm{Cu} 3$. Furthermore, Ag1-Cu2, Ag2-Cu2, Cu1$\mathrm{Cu} 1$, and $\mathrm{Cu} 1-\mathrm{Cu} 4$ contacts showed no bond critical points, placing the bonding cut-off values for the $\mathrm{Ag}-$ $\mathrm{Cu}$ contacts at about $3.05 \AA$, and that for the $\mathrm{Cu}-\mathrm{Cu}$ contacts at $2.70 \AA$.

Values of electron density calculated for the bond critical points obtained are written in Table 3 . Note that partial occupancies were not used in calculations. We believe that vacancies in some $[\mathrm{Cu} 1, \mathrm{Cu} 4]$ positions will not influence significantly the other bond critical points in this structure. All recorded contacts of As atoms with $\mathrm{Cu}$ or $\mathrm{Ag}$ are considered bonding. The $\mathrm{Cu}-\mathrm{As}$ pairs show the largest values of electron density at bond critical points (Table 3 ).

In conclusion, numerous $\mathrm{Ag}-\mathrm{Ag}, \mathrm{Cu}-\mathrm{Cu}$, and $\mathrm{Ag}-$ $\mathrm{Cu}$ bonding contacts were recorded in the structure of kutinaite. They suggest that, besides the short $\mathrm{Cu}-\mathrm{As}$ and somewhat longer $\mathrm{Ag}-\mathrm{As}$ bonds, the structure is stabilized by numerous metal-metal bonds, justifying its dual description, as given above. 
With full site-occupancies, the structural formula of kutinaite would be $\mathrm{Cu}_{64} \mathrm{Ag}_{24} \mathrm{As}_{28}$ (unit cell) or $\mathrm{Cu}_{16} \mathrm{Ag}_{6} \mathrm{As}_{7}(Z=4)$, yielding 22 positive valences versus 21 negative ones. Assuming $\mathrm{Ag}^{+}, \mathrm{Cu}^{+}$and $\mathrm{As}^{3-}$, a balanced formula requires $\mathrm{Cu}_{15} \mathrm{Ag}_{6} \mathrm{As}_{7}$ with vacancies in $\mathrm{Cu}$ positions, whereas the structurally determined vacancies give $\mathrm{Cu}_{14} \mathrm{Ag}_{6} \mathrm{As}_{7}$, in agreement with the results of the electron-microprobe analysis. This arrangement suggests presence of small amounts of $\mathrm{Cu}^{2+}$ (similar to that in domeykite, $\mathrm{Cu}_{3-\mathrm{x}} \mathrm{As}$, where $0<x<$ 0.4: Makovicky et al. 1979); on the other hand, it appears to support assignment of full valence to $\mathrm{Ag}$, contrary to the model of von Schnering \& Häusler (1976) for $\mathrm{Ag}_{6} \mathrm{Ge}_{10} \mathrm{P}_{12}$. The classical valence of $\mathrm{As}^{3-}$ was assumed in this exercise.

The bond-valence calculations (Brown \& Altermatt 1985) were performed on the structure of kutinaite, with the program IVTON (Balić-Žunić \& Vicković 1996) using the parameters of Brese \& O'Keeffe (1991). The sums of the valences obtained show a consistent, relatively large overbonding for $\mathrm{Cu}$, suggesting a relatively large proportion of nominally divalent copper, whereas for Ag, only about $(0.5)^{+}$valence is implied. An inspection of ionization potentials and electron affinities of $\mathrm{Cu}$ and $\mathrm{Ag}$ (Emsley 1994) reveals no substantial differences between the two elements. Thus we believe that the constants of Brese \& O'Keeffe (1991) for Cu-As and $\mathrm{Ag}-\mathrm{As}$ bonds are not known with sufficient accuracy. The bond-valence calculations were not pursued further.

The occupancy factors show that one half of $\mathrm{Cu} 4$ and one sixth of $\mathrm{Cu} 1$ positions are unoccupied. In each supertetrahedron (each F-subcell), there are one $\mathrm{Cu} 4$ and three $\mathrm{Cu} 1$ positions. Furthermore, there are three [As1,As2] positions per supertetrahedron. As every [As1,As2] is potentially bonded to four [Cu1,Cu4], of which two belong to the same supertetrahedron, the number of $[\mathrm{Cu} 1, \mathrm{Cu} 4]$ vacancies is consistent with three [As1,As2]-[Cu1, Cu4] bonds on average, and three $[\mathrm{Cu} 1, \mathrm{Cu} 4]$ atoms plus one copper vacancy per supertetrahedron.

$\mathrm{Cu} 4$ and As2 positions line the superoctahedral cavities that host $\mathrm{Ag}_{6}$ groups of $\mathrm{Ag} 2$ atoms, whereas $\mathrm{Cu} 1$ with As1 and some As2 positions line the cavities occupied by $\mathrm{Ag}_{6}$ groups of $\mathrm{Ag} 1+\mathrm{Ag} 3$ atoms. It is logical to assume that in each cavity with $\mathrm{Cu} 4$ and $\mathrm{Ag} 2$, one half (i.e., 4) of the $\mathrm{Cu} 4$ positions are vacant, and a homogeneous distribution of bonds about As2 positions is obtained if $\mathrm{Cu}$ atoms (or vacancies) are distributed in a tetrahedral manner around the $\mathrm{Ag}_{6}$ group. A simple exercise in the distribution of $\mathrm{Cu} 1$ vacancies in the supertetrahedra, in which $\mathrm{Cu} 4$ atoms are present (those with $\mathrm{Cu} 4$ vacancies should have all three $\mathrm{Cu} 1$ positions occupied) and then through the other adjacent supertetrahedra, shows that no completely homogeneous distribution of vacancies through the structure is possible. Inevitably, there are some [As1,As2] atoms for which four $[\mathrm{Cu} 1, \mathrm{Cu} 4]$ neighbors result, and some with only two. Such a situation explains why no complete ordering of vacancies is observed (i.e., no lowering of symmetry from cubic), and suggests a domain-like crystal structure, with a local order for some positions $(\mathrm{Cu} 4)$ but without long-range order between the various cavities with $\mathrm{Cu} 4$ and $\mathrm{Ag} 2$. This arrangement results in an average $P m \overline{3} m$ structure and also suggests that the stable high-temperature structure of kutinaite is a $F m \overline{3} m$ one with a dynamic disorder of vacancies and the same average composition of three $\mathrm{Cu}$ and one vacancy per supertetrahedron. The observed metastable low-temperature structure is probably a result of a frozen local ordering of vacancies. Complete ordering of vacancies is impossible without a reconstructive transformation to a new structure-type.

\section{ACKNOWLEDGEMENTS}

This project was supported by grant no. 9901772 of the National Research Council (Natural Science) of Denmark. We thank the Institute of Mineralogy and Crystallography of the University of Göttingen and Prof. P. Susse for allowing data collection on their instrument. The assistance of Mrs. Camilla Sarantaris and the helpful comments of Prof. H. Effenberger, Dr. P. Berlepsch and Prof. R.F. Martin are gratefully acknowledged.

\section{REFERENCES}

BADER, R.F.W. (1990): Atoms in Molecules: A Quantum Theory. University of Oxford Press, Oxford, U.K.

BALIĆ-ŽUnić, T. \& MAKovicky, E. (1996): Determination of the centroid or "the best centre" of a coordination polyhedron. Acta Crystallogr. B52, 78-81.

\& Vicković, I. (1996): IVTON - a program for the calculation of geometrical aspects of crystal structures and some crystal chemical applications, J. Appl. Crystallogr. 29, 305-306.

BÉRAR, J.-F. \& LELANN, P. (1991): E.s.d.'s and estimated probable error obtained in Rietveld refinements with local correlations. J. Appl. Crystallogr. 24, 1-5.

BLENDL, C. \& RANGe, K.-J. (1982): $\mathrm{Cu}_{3} \mathrm{As}_{4}$ - eine Kolumnarstruktur mit polykondensierten hetero-nuklearen Cunean-Einheiten. Z. Kristallogr. 159, 17-18.

BRESE, N.E. \& O'KeEFFe, M. (1991): Bond-valence parameters for solids. Acta Crystallogr. B47, 192-197.

Brown, I.D. \& Altermatt, D. (1985): Bond-valence parameters obtained from a systematic analysis of the inorganic crystal structure database. Acta Crystallogr. B41, 244-247.

Clementi, E. \& Roetti, C. (1974): Atomic data and nuclear data tables: Roothaan-Hartree-Fock atomic wave functions. Academic Press, New York, N.Y. 


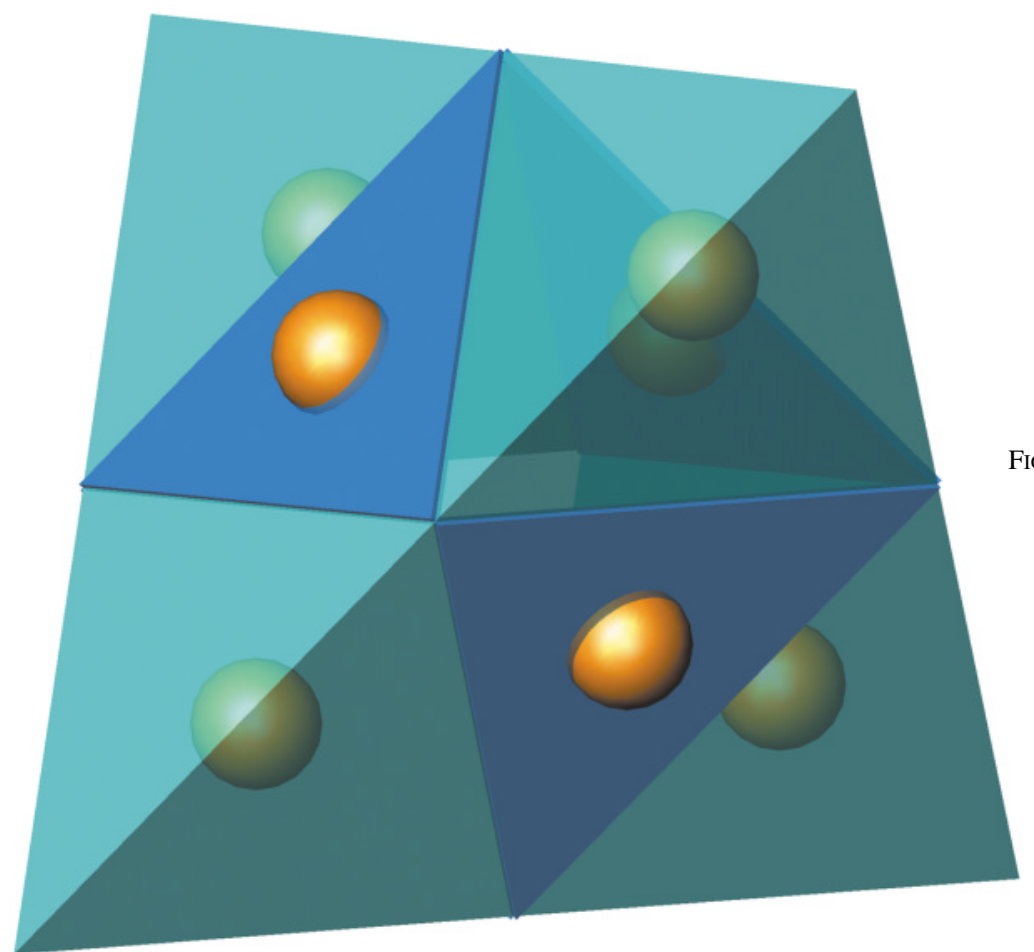

FIG. 6. Supertetrahedron composed of $[\mathrm{Cu} 2, \mathrm{Cu} 3] \mathrm{As}_{4}$ tetrahedra and $[\mathrm{Cu} 1, \mathrm{Cu} 4] \mathrm{As}_{3}$ triangles $(\mathrm{Cu}$ atoms shown as spheres).

FIG. 7. A polyhedron representation of the structure of kutinaite, with supertetrahedra (blue) and $\mathrm{Ag}_{6}$ octahedral groups (grey) outlined. Purple: arsenic atoms, orange: $[\mathrm{Cu} 1, \mathrm{Cu} 4]$ in trigonal-planar coordination (dark blue polyhedra), yellow-green: [Cu2,Cu3] in tetrahedral coordination (turquoise polyhedra).

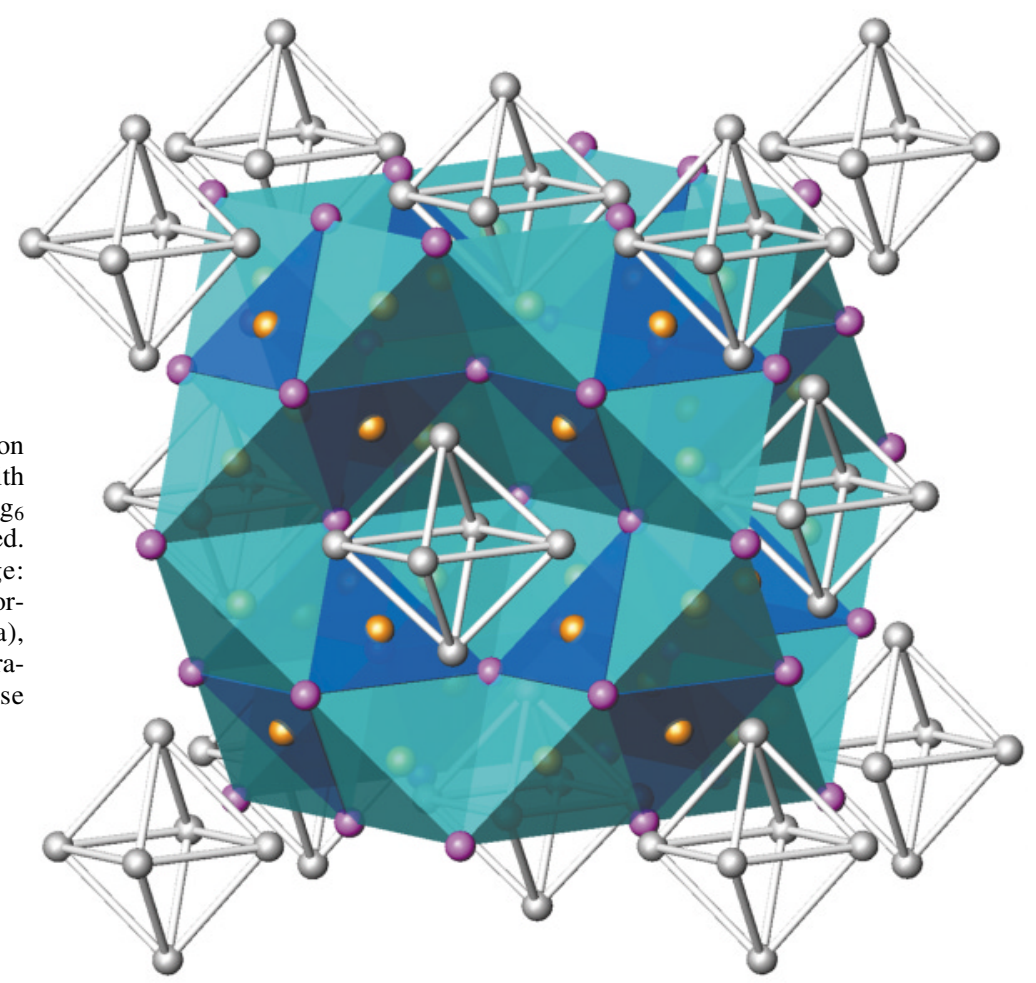


Emsley, J. (1994): The Elements (2nd ed.). Clarendon Press, Oxford, U.K.

Gibbs, G.V., Spackman, M.A. \& Boisen, M.B., JR. (1992): Bonded and promolecule radii for molecules and crystals. Am. Mineral. 77, 741-750.

HAK, J., Johan, Z. \& Skinner, B. J. (1970): Kutinaite; a new copper-silver arsenide mineral from Cerný Důl, Czechoslovakia. Am. Mineral. 55, 1083-1087.

Iglesias, J. E. \& Nowacki, W. (1977): Refinement of the crystal structure of $\alpha$ domeykite, a structure related to the A15 type. Z. Kristallogr. 145, 334-345.

Karanović, Lj., Petrović-Prelević, I. \& Poleti, D. (1999): A practical approach to Rietveld analysis. Comparison of some programs running on personal computers. Powder Diffract. 14, 171-180.

LIEBISCH, W. \& SchubeRT, K. (1971): Zur Struktur der Mischung Kupfer-Arsen. J. Less-Common Metals 23, 231-236.

Makovicky, E. \& BALić-Žunić, T. (1998): New measure of distortion for coordination polyhedra. Acta Crystallogr. B54, 766-773.

Makovicky, M., Rose-Hansen, J. \& Skinner, B.J. (1979): Phases and phase relations in the system $\mathrm{Cu}-\mathrm{Ag}-\mathrm{As}$ at $500^{\circ} \mathrm{C}, 400^{\circ} \mathrm{C}$ and $350^{\circ} \mathrm{C}$. Neues Jahrb. Mineral., Abh. 135, 221-269.

Mansmann, M. (1965): Über Verbindungen vom Anti-LaF $3^{-}$ Strukturtyp. Z. Kristallogr. 122, 399-406.

McCusker, L.B., Von Dreele, R.B., CoX, D.E., LouËr, D. \& SCARDI, P. (1999): Rietveld refinement guidelines. J. Appl. Crystallogr. 32, 36-50.
NAud, J. \& Priest, P. (1972): Contribution à l'étude du système cuivre-arsenic. Mat. Res. Bull. 7, 783-792.

O’Keeffe, M. \& Hyde, B.G. (1996): Crystal Structures. I. Patterns and Symmetry. Mineralogical Society of America, Washington, D.C.

RODRÍGUEZ-CARVAJAL, J. (1990): FULLPROF: A program for Rietveld refinement and pattern matching analysis. Satellite Meeting on Powder Diffraction of the XV Congress of the IUCr (Toulouse), 127 (abstr.).

(1998): Short Reference Guide of the Program FULLPROF (version 3.5d). Laboratoire Léon Brillouin, CEA-CNRS, France.

ROISNEL, T. \& RODRÍGUEZ-CARVAJAL, J. (2001): WinPLOTR: a Windows tool for powder diffraction analysis. In Materials Science Forum. Proceedings of the European Powder Diffraction Conf. (EPDIC 7), in press.

SHELDRICK, G.M. (1997a): Program for the solution of crystal structures, SHELXS97. University of Göttingen, Göttingen, Germany.

(1997b): Program for the refinement of crystal structures, SHELXL97. University of Göttingen, Göttingen, Germany.

Spackman, M.A. \& MASLEN, E.N. (1986): Chemical properties from the promolecule. J. Phys. Chem. 90, 2020-2027.

von Schnering, H.G. \& HÄUsLer, K.G. (1976): $\operatorname{Ag}_{6} \mathrm{Ge}_{10} \mathrm{P}_{12}$, Eine Verbindung mit $\mathrm{Ag}_{6}$-Cluster. Revue de Chimie minérale 13, 71-81.

Received April 7, 2002, revised manuscript July 12, 2002. 